\title{
Positioning Technical and Vocational Education and Training for Sustainable Development in Africa Taking Cue from the Chinese Model
}

\author{
Adekunle Osidipe \\ China Africa Education Cooperation Research Center, Institute of African Studies, Zhejiang Normal \\ University, 688, Yingbin Avenue, Jinhua, Zhejiang Province, China 321004 \\ * klexym@163.com
}

\begin{abstract}
The general consensus among countries globally is that TVET plays significant role in economic development, but the increased awareness notwithstanding, provision of TVET in African countries is hampered by diverse constraints as many countries on the continent have not been able to make quality provisions for TVET at a level that can support quality training. The continent faces the enormous challenge of providing stable and sustained socio-economic development that will provide room to lift the young population out of poverty induced by unemployment and protect the continent from poverty-triggered insecurity. The development of Africa has been hinged on quality investment in human capital development in the face of the changing dynamics in the world of work and the future of jobs. In order to achieve this, it is imperative for African countries to adopt different approach to the delivery of TVET on the continent. The Chinese experience in delivery of TVET, built on sound policy framework, effective funding system coupled with rural development-driven TVET provision, robust TVET institution and enterprises linkage as well as consistent teacher training programme, provide a viable example for emulation in the design and implementation of effective TVET delivery that will guarantee sustainable development on the continent.
\end{abstract}

Key Word: TVET, Development, Africa, China

DOI: $10.7176 / \mathrm{JAAS} / 56-09$

Publication date:July $31^{\text {st }} 2019$

\section{Introduction}

Africa's population is huge and growing, with about 1.3 billion people, and an annual growth rate of $2.7 \%$, the continent is blessed with a vibrant youth population which has $75 \%$ under the age of 25 years (ILO, 2019; UN, DESA, \& Pupulation Division, 2017). The growing youth population must be captured within inclusive growth and development policies that engender quality and effective education, job creation and access to growth enabling public services in order to ensure social, economic and political stability on the continent. The state of education on the continent calls for urgent concerted efforts, while much has been done in primary education with primary school enrolment put at $97.3 \%$, secondary school enrollment is just $42.8 \%$. At the tertiary level, a dismal $9.3 \%$ were enrolled in higher education as at 2017. Enrolment in TVET on the continent paints a gloomier picture when compared with that in the secondary and tertiary education levels with less than $5 \%$ access to formal secondary school TVET in the region (AFDB \& OECD, 2008; UNESCO, 2019). The consistent neglect of TVET by various countries on the continent since the time of their independence significantly reflected in the scarcity of data on TVET in most of the countries. The most recent statistics on TVET enrolment in Africa is drawn from the global survey on access to formal TVET worldwide by the UNESCO Institute of Statistics in 2006. There is prevalent dismal enrolment in TVET on the continent when compared to other regions of the world coupled with continuous decline of public expenditure on education due to misguided fiscal policies adopted on the recommendation of global lenders to reduce government expenditure on education, especially TVET, and drastic crash in global commodity prices which limited available funds to governments in African countries. In countries like Eritrea, Ethiopia, Malawi, Namibia, Niger and Uganda, female enrolment accounted for less than 15\% in the total TVET enrolment and the share of TVET enrolment in overall secondary enrolment is less than $5 \%$. 


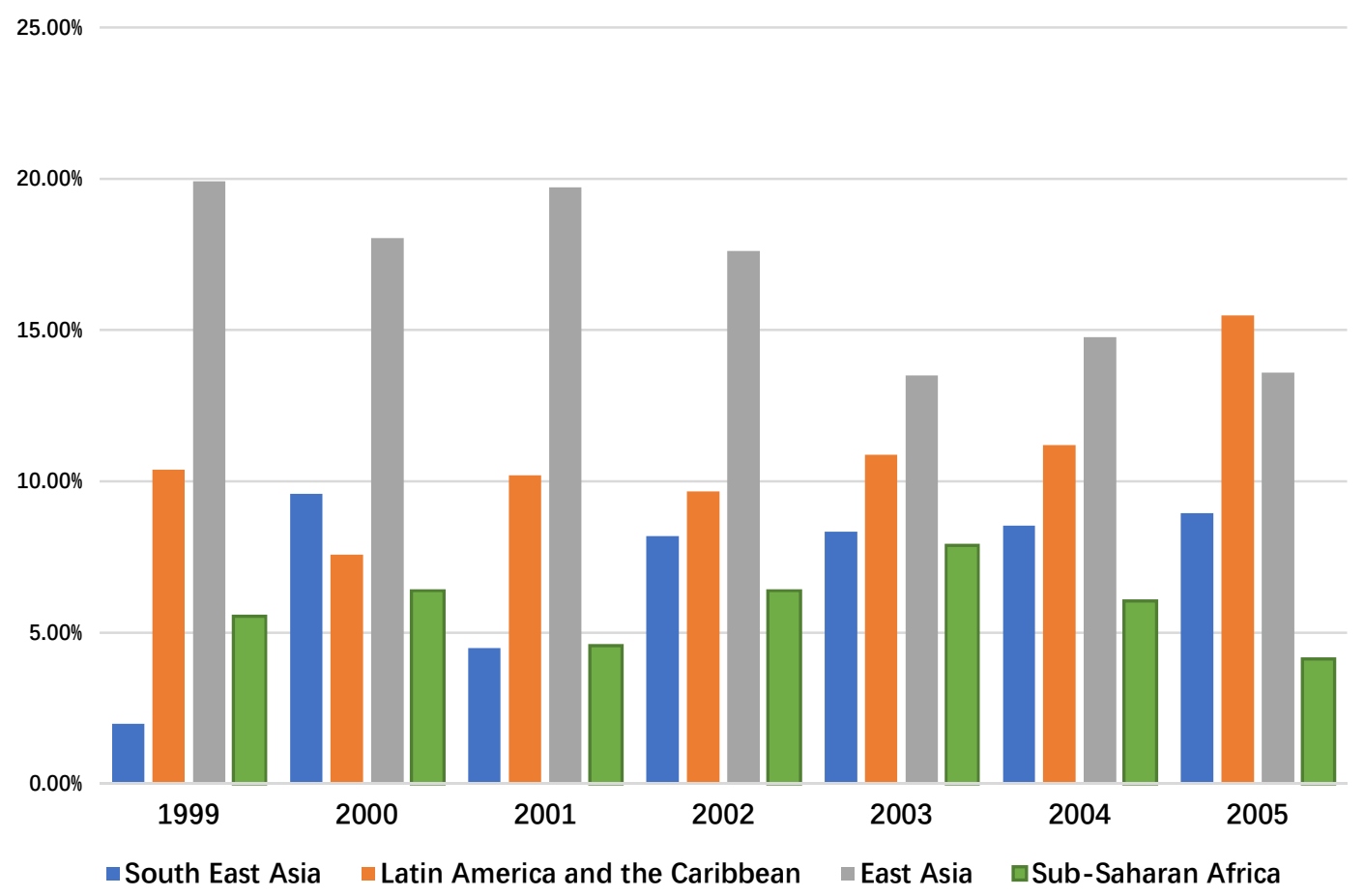

Figure 1: TVET as a Percentage of Total Secondary Enrolment Source: Adapted from AFDB \& OECD (2008), based on UIS statistics http://dx.doi.org/10.1787/315817350525

Unemployment, under-employment and youth engagement in anti-social activities are widespread on the continent due to the lack of adequate productive outlets where they can be engaged to make their contributions to the development of their immediate environments as responsible members of the society. The continent bourgeoning young population presents an opportunity to trigger rapid development coupled with a growing labour force with attendant potential growth opportunities. But how can Africa reap the benefits presented by these opportunities? In an increasingly dynamic knowledge-based and information driven global economy, every society requires the services and contributions of knowledgeable and technically skilled workforce who are conversant with the dynamics of their work environment. The neglect of TVET system has resulted in shortage of technical skilled manpower on the continent.

China has gone through several stages of development in nation building and education. Worthy of note is that the TVET system in China equally faced the several common challenges including that of low attractiveness, inadequate teacher training as well as funding like most other developing countries of the world. Despite all these, the country evolved a unique TVET system responsive to national development needs. One of the attributes of this uniqueness of Chinese TVET system is that the system did not follow the supply-led syndrome, it was demanddriven (Archer, 2013). Others are the funding system provided by the government to prop the nation building process as well as the combination of investment from the private sector (Chen, 2016b; Guo \& Lamb, 2010; Wu \& Ye, 2009). China provides a most reliable example for developing African countries in designing and implementing development-driven TVET system that will promote sustainable growth and development on the continent.

\section{Technical and Vocational Education and Training (VET) Defined}

In defining technical and vocational education, a major reference is the broad definition of technical and vocational education used in the UNESCO and ILO Recommendations on TVET for the Twenty-first Century:

"as a comprehensive term referring to those aspects of the educational process involving, in addition to general education, the study of technologies and related sciences, and the acquisition of practical skills, attitudes, understanding and knowledge relating to occupations in various sectors of economic and social life." 
TVET refers, therefore, to a range of learning experiences that are relevant for the world of work and which may occur in a variety of learning contexts, including educational institutions and workplaces. TVET encompasses formal learning (provided in educational institutions or by public/private providers, as well as on the job) and nonformal learning (learning within or outside the workplace, usually outside educational institutions, such as traditional apprenticeship), aiming to ensure that all members of the community have access to the pathways of life-long learning. TVET includes both initial vocational training undertaken by young people prior to entering the labour market and continuing vocational training undertaken by adults whilst in work or during periods in which they are economically inactive. The Recommendations understand technical and vocational education as:

(a) an integral part of general education;

(b) a means of preparing for occupational fields and for effective participation in the world of work;

(c) an aspect of lifelong learning and a preparation for responsible citizenship;

(d) an instrument for promoting environmentally sound sustainable development;

(e) a method of facilitating poverty alleviation.” (UNESCO \& ILO, 2002).

\subsection{The Challenges of TVET and Imperative of China's Model for Development in Africa}

TVET faces multifaceted challenges in Africa including poor funding, inadequate qualified teaching personnel, social stigma among others. However, the root of the challenges is traceable to misconception of the meaning and purpose of TVET in the development of the African countries as well as external influence from international donor agencies. The lack of a dedicated TVET policy in many countries on the continent is a signal to the lack of commitment on the part of the government to this important sector of education and also a pointer to the misconception (Dike, 2009; Federal Ministry of Education Nigeria, 2005; K.R.E. Okoye, Okwelle, 2014; Moja, 2000) and the misinterpretation (Moja, 2000) of the meaning and significance of TVET among the policy makers. The general perception in the society about technical and vocational education is that it is an education designed for dropouts and less intelligent learners; the last option for low performing students or the education for the never do wells among regular education students. This has resulted in the inability of TVET institutions to attract high aptitude students and those who eventually got admitted into TVET programmes barely pass through the programmes with no motivation due to poor aptitude and attitude (Oviawe, 2015).

The misconception that learners who enroll in TVET are only good at working with hand tools such as hammers, screwdrivers, and spanners or wrenches (Dike, 2009; Okoye \& Arimonu, 2016) also impacted on the way jobs are assigned, salaries paid, and the time and type of promotions received by graduates of TVET. For example, in Nigeria, due to misconception of TVET, there is an overt preference for university graduates with bachelor's degrees over graduates of Polytechnics who possess Higher National Diploma (HND). With the preference also comes disparity in salaries between university graduates and polytechnic graduates (Dike, 2009; Moja, 2000; Oni, 2006). There is general critical disconnect between the perspectives of those involved in making and implementing economic and development policies in many countries on the continent which can be seen in the limited level of support for TVET programs. The consequence is the acute shortage of highly skilled middle and high-level technical manpower to drive critical sectors and institutions of the economy.

In terms of external influence, immediately following the independence of most African countries in the 1960 s and up till the late 1970s, most of them adopted TVET to meet expected skill requirements of industrialization and ease the problem of unemployment among the young school graduates. However, concerns raised by the World Bank's rate of returns studies that showed higher returns on investment in general education than vocational education led to a drastic shift of interest to the funding of general basic education at the expense of funding of TVET. During the period between 1980s and 1990s, the World Bank's lending for TVET to the African region dropped sharply more than $40 \%$, compared to other parts of the world (Bennell \& Segerstrom, 1998). This affected the bank's financed education training projects and undermined much external support for TVET. From this point, the attractiveness of TVET began to wane as education provision in many African countries leaned mainly towards the general pathway and TVET considered as option for the low achievers.

The World Bank's decision adversely affected the development of TVET in most developing countries; especially, in Sub-Saharan Africa considering the fact that most of the countries newly got independence and were unable to fully finance TVET provisions effectively without external lending. Though the Bank's decision has been criticized, the nascent growth of TVET in most African countries was effectively truncated by the Bank's decision which was followed by years of prevalent imbalance in education structure, underfunding of TVET, skills shortages, skills mismatch and massive unemployment coupled with stagnant economies on the African continent. The policies of the international lending organizations, like the world bank, were primarily influenced by the 
conception that investment in TVET is investment in human capital as a means to supporting economic growth, where the underlying view of development in operation is an economic one in which "progress" is measured in relation to levels of economic growth and prosperity (Tikly, 2013).

The arguments of pro-economic perspective researchers have been criticized by other researchers who contended that the earlier failure of TVET in some developing countries should not be construed as a condition that TVET cannot succeed in other developing countries. Some of the scholars believe that the failure of TVET in developing countries has to do with the influence of the "Western paradigm" (Watson, 1994), which has consistently held sway in the developing countries despite their independence from the West. The effects of this include:

a. That too many governments have been swayed by the arguments put forward by multinational agencies, with the result that there has frequently been a disturbing disregard for indigenous opportunities and the reality of the local environment.

$b$. That the dependency culture, seen in terms of overseas training, course evaluations and assessment, the use of expatriate staff and Western equipment and machinery, has prevented the development of truly indigenous programmes, except where intermediate technology/self-help programmes have prevailed (Watson, 1994, p. 92).

In addition, Bennell and Segerstrom (1998) questioned the negative disposition of the World Bank to TVET and described the Bank's action to withhold TVET funding in the context of an expanding education sector budget an ideologically driven over-reaction justified on the basis of a serious mis-reading of the evidence concerning the role of public sector TVET at all stages of economic development. However, according to Lewis (2009), contrary to decades of policy edicts and supporting research, investment in formal vocational education does not always come to failure. Bennell and Segerstrom (1998) cited Korea and Taiwan as examples of countries that successfully relied upon state-funded specialized vocational education in secondary schools in their early period of industrialization period. In Korea firms relied on government sponsored training, enterprise training tending to be unreliable.

Globally, most countries recognized that essential sectors critical to national development like agriculture, construction, manufacturing, transportation, communications and commerce for example require a massive pool of skilled manpower, and that it is through TVET that such manpower can be obtained. Also, various studies have shown that whether in developed or developing economies, investment in TVET is worthwhile (Adams, Johansson de Silva, \& Razmara, 2013; Dike, 2009; Osidipe, 2017; UNESCO \& ILO, 2002; Xiulan, 2011). In recent years, global attention has shifted back to TVET as indispensable platform for provision of relevant knowledge, skills and competencies in the face of rising unemployment, inequality, poverty, and amidst changing work requirements due to rapid technological advancement. TVET has been described as a crucial platform for the acquisition of skills and knowledge for employment and sustainable livelihood (Maclean \& Wilson, 2009). There is general belief that TVET provides the needed employable skills and attitudes necessary for effective performance in the workplace.

Major reforms are being carried out in different countries globally consequent on the increasing recognition of the crucial role that higher technical skills play in enhancing competitiveness, social inclusion, decent employment and poverty reduction. The ILO Decent Work Agenda identified the development of relevant skills as key to improved productivity and working conditions as well as promoting decent work in the informal economy (Adams, 2008; AFDB \& OECD, 2008). Also, in recognition of the significance of TVET in education with the aim of developing human and social capital through skills revolution emphasizing innovation, science and technology, the African Union set up the Continental Education Strategy for Africa (CESA) with wide ranging objectives for development of education on the continent which includes to "expand TVET opportunities at both secondary and tertiary levels and strengthen linkages between the world of work and education and training systems." This was followed by the African Union Continental Strategy on TVET providing a framework for the reform and repositioning of TVET on the continent (African Union, 2007).

The dynamics of changes in the world of work and the future of jobs make it more imperative for African countries to scale up efforts at nurturing knowledgeable and skilled workforce. While some jobs are being threatened by redundancy, the demands for some are on the increase, also some jobs require constant changes in the skills set in order to remain relevant (World Economic Forum, 2016). The increasing influence of globalization on national economies, has made learning become lifelong with its foremost skill being learning how to learn (Wilson, 2001). The desire of the continent to have trained workforce in the face of changing world of work is realizable if the nexus between TVET and skills development is adequately harnessed by effectively integrating skills and knowledge acquisition program into the development programmes of countries on the continent. 
Many African countries have engaged in working towards improving the quality and skills levels of their labour forces. However, the impact of technical and vocational training on the "employability" of the labour force is not only a matter of the quality of skills acquired, but on the dynamism of the economic environment in which the skills learnt can be applied. It has been observed that investment in skills development in rapidly growing economies tend to have high returns than in situations characterised by weak growth and poor governance (AFDB \& OECD, 2008). Therefore, provision of TVET must go beyond ordinary skills acquisition and include simultaneous implementation of reforms that engender the promotion of inclusive growth, expansion of opportunities for business development and employment, with emphasis on skills development for the sectors with the most promising employment prospects in order to have measurable impacts.

China, as the largest developing country in the world, has become a model for many other developing countries seeking space in the global economy (Kurlantzick, 2005). As a developing country that has attained rapid development through investment in TVET in contemporary period, China is the most feasible and appropriate example for developing countries. The question that may come to mind may be: "why the Chinese model for African countries? Starting from 1963, the World Bank provided significant funds for TVET in developing countries and continued all through 1964-1969. By 1976, the Bank's lending to TVET occupied 51\% of the total education expenses of the Bank. The programme was discontinued from the 1980s and by 2002, the rate was just about $9 \%$ of the total expenditure on education. The Bank's de-emphasized investment in TVET and asked developing countries to focus on investing in more economically profitable things. TVET began to decline as other international donors followed suit and shifted attention away from TVET (Bennell \& Segerstrom, 1998; Psacharopoulos, 1990). Though the World Bank officially owned up about this three decades later (The News, 2018), the admission came rather too late, but not too late for the developing countries. China forged ahead by investing in TVET all through the time African countries were toeing the line of World Bank's experts instructions to scale down funding TVET. The consequences of the economic reforms were not favourable to development of education, especially TVET in African countries and other developing countries that toed the same line (Bennell \& Segerstrom, 1998).

A look at the consequences of the actions taken by three large developing countries of China, India and Nigeria during the period of shifting investment away from TVET to other sectors could be seen a decade later in the rising gaps in the GDP per capital of these countries as shown below:

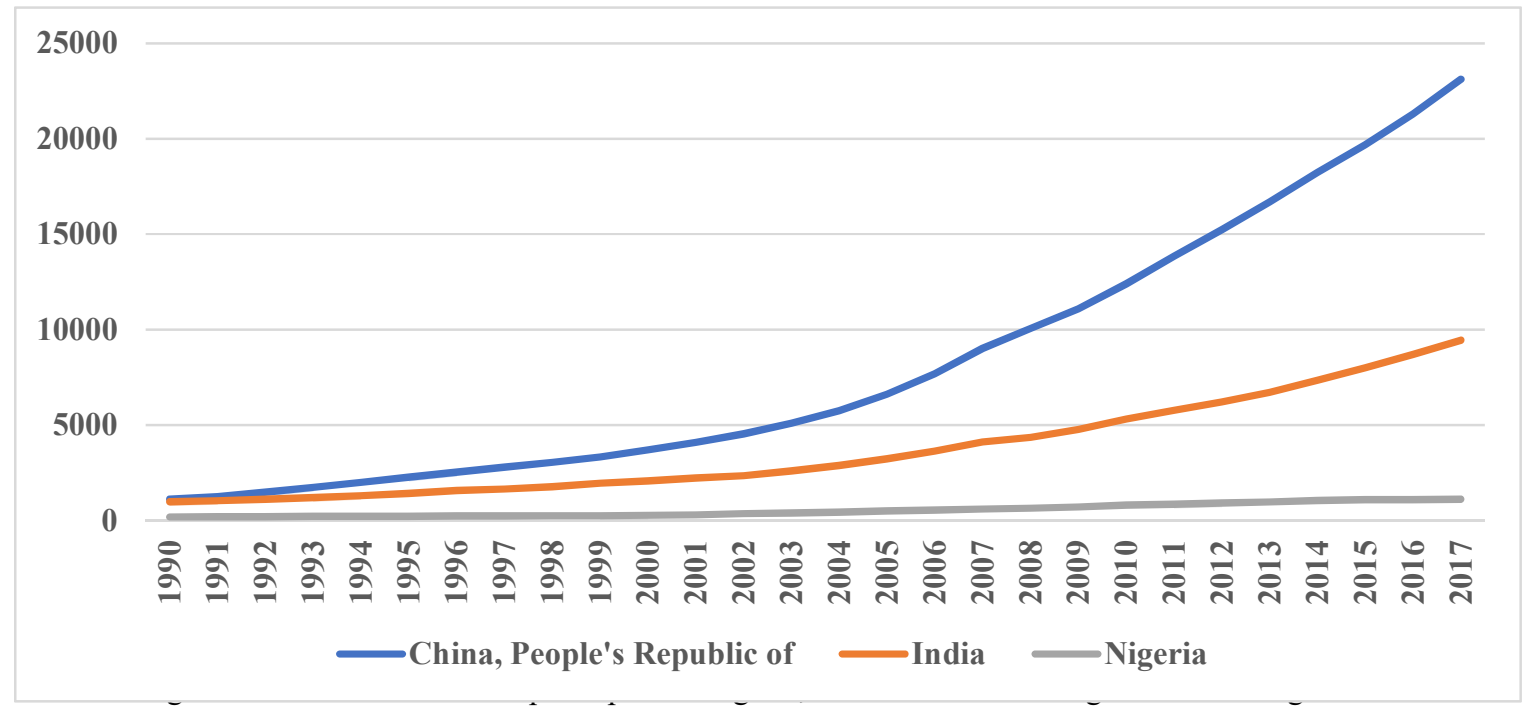

Figure 2 GDP Per Capita, current prices (Purchasing power parity; billions of international dollars)

same "analytical group" classitied by the International Nionetary rund (IVIF) as "Emerging IVIarkets and Developing Economies" and are characterized by significantly large populations. It is noteworthy that the difference in GDP per capita among the trio was relatively negligible between the early 1990s and the late end of the 1990s, but this took a new turn as the gap widens and continues to enlarge from the early 2000s. The Chinese successful experience in TVET could serve as boost needed to trigger the much- needed growth and development in Africa. 


\section{Lessons from China's Development-Driven TVET Model}

The Chinese experience provides a model in effective synergy of various sectors of the economy in phased development programme. Many studies have linked China's gradual and consistent rise to global power within three decades to the unique provision of school based TVET (Chen, 2016a; Keating, Medrich, Volkoff, \& Perry, 2002; Wu \& Ye, 2009; Zhaoli, 2013). China's consistent rise to global limelight as a leading industrial nation no doubt is closely connected to the country's focus on human capital development through the provision of development-driven TVET that is relevant to the need of the society at every stage of development. Within three decades, the country has transformed into a global manufacturing base, and experienced structural transformations in the economy. For instance, between 1990 and 2015, the percentage of the population employed by agriculture declined significantly from $60.1 \%$ to $28.3 \%$. On the other hand, the population employed in the manufacturing (secondary sector) and services (tertiary industry) sectors of the economy increased to $29.3 \%$ and $42.4 \%$ respectively.

\begin{tabular}{|l|l|c|c|c|c|c|}
\hline \multirow{2}{*}{} & \multicolumn{2}{|c|}{ Agriculture } & \multicolumn{3}{c|}{$\begin{array}{c}\text { Manufacturing/ } \\
\text { Construction }\end{array}$} & \multicolumn{2}{c|}{} \\
\cline { 2 - 7 } & Output (\%) & $\begin{array}{c}\text { Employment } \\
\text { proportion (\%) }\end{array}$ & $\begin{array}{c}\text { Output } \\
(\%)\end{array}$ & $\begin{array}{c}\text { Employment } \\
\text { proportion (\%) }\end{array}$ & $\begin{array}{c}\text { Output } \\
(\%)\end{array}$ & $\begin{array}{c}\text { Employment } \\
\text { proportion (\%) }\end{array}$ \\
\hline 1990 & 27.1 & 60.1 & 41.3 & 21.4 & 31.6 & 18.5 \\
\hline 1995 & 19.9 & 52.2 & 47.2 & 23.0 & 32.9 & 24.8 \\
\hline 2000 & 15.1 & 50.0 & 45.9 & 22.5 & 39.0 & 27.5 \\
\hline 2004 & 13.4 & 46.9 & 46.2 & 22.5 & 40.4 & 30.6 \\
\hline 2006 & 11.7 & 42.6 & 48.9 & 25.2 & 39.4 & 32.2 \\
\hline 2008 & 11.31 & 39.6 & 48.62 & 27.2 & 40.07 & 33.2 \\
\hline 2010 & 10.1 & 36.7 & 46.7 & 28.7 & 43.2 & 34.6 \\
\hline 2012 & 10.1 & 33.6 & 45.3 & 30.3 & 44.6 & 36.1 \\
\hline 2014 & 9.2 & 29.5 & 42.7 & 29.9 & 48.1 & 40.6 \\
\hline 2015 & 9.0 & 28.3 & 40.5 & 29.3 & 50.5 & 42.4 \\
\hline
\end{tabular}

Table 1: GDP Contribution and Employment Population Distribution by Industry (National Bureau of Statistics China, 2016b)

The gradual drop in the employment proportion in primary industry and steady rise in the employment proportion in the secondary (manufacturing) and tertiary (services) industries signals significant increment in the number of skilled manpower available for employment in the latter two sectors. Furthermore, due to the continued growth in socio-economic development in China, the living conditions of the general population continues to rise with corresponding increase in the number of residents living in cities (not due to rural -urban migration, but due to the transformation of hitherto rural areas into modern cities). This can be seen in the table below showing the percentage of urbanization in China between 1978 and 2014:

\begin{tabular}{|l|l|l|l|l|l|l|l|l|l|}
\hline 1978 & 1990 & 1995 & $\mathbf{2 0 0 0}$ & $\mathbf{2 0 0 4}$ & $\mathbf{2 0 0 6}$ & $\mathbf{2 0 0 8}$ & $\mathbf{2 0 1 0}$ & $\mathbf{2 0 1 2}$ & $\mathbf{2 0 1 4}$ \\
\hline $\mathbf{1 7 . 9 0}$ & 26.4 & 29.04 & 36.22 & 41.76 & 43.90 & 44.90 & 50.00 & 53.00 & 55.00 \\
\hline
\end{tabular}

Table 2: Percentage of Urbanization Level in China (National Bureau of Statistics China, 2016a)

China experienced clear shift from an agricultural and primary goods-based economy of the pre-reform era to an industrialized economy combined with highly efficient service economy. This does not mean that China abandoned agriculture, because the industry still employs a large portion of China's active work force with a little over 300 million people employed in 2008. The agricultural sector has witnessed significant improvement and higher productivity than the pre-reform era. The manufacturing sector is a key contributor to the country's employment and GDP, it is the main driving force behind the Chinese economic growth. Therefore, African countries in the quest for sustainable development can take cue from the Chinese successful experience and the opportunity of the BRI to provide effective TVET delivery focused on the development of key sectors of the economies of the countries on the continent. The investment of China in TVET to meet the country's desire for 
industrialization and transformation of the economy has significant positive consequences as the country has risen from once agrarian and poor country to become the largest industrial country and the second largest economy in the world. Key factors engaged by China in delivery of TVET include putting inn place strong policy framework, effective funding, promotion of rural development through TVET, promotion of TVET-enterprise linkage, and consistent teacher development programme.

\subsection{Strong Policy Thrust}

A significant step taken by the Chinese government in developing TVET in the country is the enactment of the 1996 Vocational Education Law of the People's Republic of China, which provides the legal support for technical and vocational education in the country. The Law encourages students to take up technical and vocational stream in post junior secondary education, clearly stipulates the different roles and responsibilities of the various stakeholders in the TVE system providing for rural economic development through the promotion of technology and rural technical and vocational education. Most countries in Africa have no dedicated TVET policy, for example, Nigeria the country with the largest population on the continent does not have a technical and vocational education law or policy, the only existing policy provision exists within the general national policy of education (NPE). Efforts must be made by African countries to enact dedicated and focus-driven TVET policy to provide a more distinct and stable legal framework for TVET delivery to meet the continent's demand for skilled manpower and solve the problem of unemployment.

\subsection{Effective TVET Funding}

The 1996 Vocational Education Law in China requires that 20 per cent of the annual education budget should be allocated to vocational education and training. The system of fiscal decentralization in China and autonomy of the local governments significantly enhances the implementation of technical and vocational education, benefits local enterprises, due to the flexible TVET system that responds to local needs, as well as benefits the students in terms of employment. The local governments make appropriations for funding of TVET from locally generated revenue and provide such funds also for rural vocational training. As a matter of policy, local industries are required to utilize $1.5 \%$ of their payroll for in-service training. If the industries could not do this, they shall pay the equivalent in tax to the government to be disbursed for adult training. One major feature of the global scale rapid development in Chinese education system (including TVET) is the concept of "Key schools/educational institutions" which was born out of the need to effectively utilize available scarce resources to develop the education sector. Faced with the dire challenges of shortage of skilled manpower to drive the growth of national economy and limited finances, the Chinese government decided to pool together available scarce resources to build key schools/institutions.

Technical and vocational education is under the control of the local governments and majority of the funding of technical and vocational education is provided by the local governments. The government takes care of about $71 \%$ of the entire expenditure on technical and vocational education through annual budgetary appropriations (Figure 3). According to the Vocational Education Law of 1996, the local governments at the county levels (i.e. sub-provincial level) have the responsibility to sponsor vocational education in schools and training institutions. Article 30 of the Law mandates the provincial governments, autonomous regions and municipalities to set aside funds for vocational education from the local charges they collect for education under the Education Law. The Law also specifies that the governments may appropriate funds for rural vocational training from the funds earmarked for developing agricultural science and technology. Provision was made in the Law to give tuition waiver for students in vocational education and training with financial difficulties or disability. 


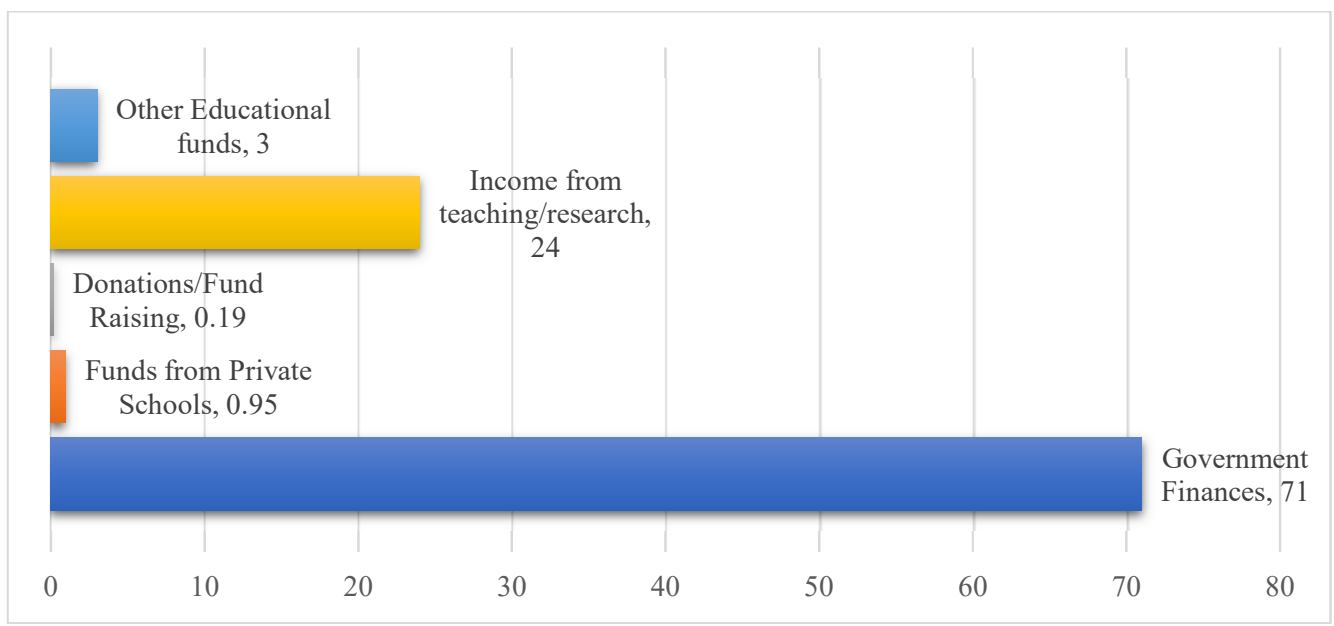

Figure 3: Source of TVET Funding Source: (Ministry of Education PRC, 2015)

Over 70 per cent of the funding for vocational schools at the secondary level comes from government finances, almost all of them by local governments. However, it is only in the case of Regular Specialized secondary schools and Technical schools (under MOHRSS) that the share of government finances is less than 70 per cent. These schools receive a greater proportion of funds from teaching, research and other supplementary sources.

\subsection{Rapid Development of Rural Areas through TVE}

China is the largest developing country in the world with one quarter of the world population, with significant portion of the country's population and that of the student residing in the countryside. The government adopted development of TVET as a tool to realize the objectives of peace, prosperous communities, social stability, and sustainable development. The student population in technical and vocational colleges in rural areas has increased with rural vocational education delivered by the specialized secondary schools of agriculture and forestry, rural vocational high schools and technical colleges which tailored to local needs as reflected in their program structure and curricular. There are dynamic relationships between Vocational training schools and employers encompassing quality training, and the curriculum flexibility that responds to the highly dynamic and competitive environments. TVET is socially relevant in the area of equity, such as in terms of access for vulnerable groups of people, and more broadly, the role of the system in reducing poverty (Asian Development Bank, 2009).

\subsection{TVET Institution-Enterprise Collaboration}

China's TVET policy emphasized four main areas of implementation including skilled personnel training, transformation of rural labour, practical rural labour training and in-service and re-employment training. The content of the training projects is to strengthen professional ethics of TVET graduates, develop vocational skills and guidance through vigorous promotion of work-study integration and school-enterprise linkages. The schoolenterprise linkages was backed up with the policy document "The Report on Reform of the Structure of Secondary Education" by the Ministry of Education and the National Bureau of Labour and released by the State Council in 1980. The policy recommended the establishment of vocational institutions to strengthen the linkages to meet the demands of new open-door economic policies. This policy document is considered to be the first in a series of TVET reforms in China, as it clarified government's position on the TVET and enterprise linkage (NCVER ,2005). Industries in China actively participate in practical training for interns and local governments on the other hand provide incentives to local enterprises such as land allocation at subsidized rates, or preferential treatment in case of award of government projects (IAMR, 2013). Such measures prove to be influential in encouraging industry to actively participate in vocational education and training

\subsubsection{Models of TVE Institution-Enterprise Collaboration}

Ying (2009) cited by Joo (2013) identified four models out of several other models of TVE industry collaboration at the service delivery level which have been developed in China as part of efforts to enhance TVE industry linkages. These models include:

\section{(a) Mutual Cooperation Between Enterprise and School' Model}

The model is based on the belief that collaboration brings mutual benefits to both sides. The enterprise's benefits are the improvement of industrial production processes and productivity, while the TVE school (provider) benefits are accessing enterprises' equipment/expertise as well as gaining direct financial support from those same 
enterprises. Both the company and school have experienced the mutual benefits that can be derived from collaboration, that is, technology advances and increased production.

\section{(b) The Training by Order Model}

Unlike the first model, the provider selects a specific enterprise for the partnership. Upon the agreement, the institution offers specialized courses and reorganizes the teaching structure to meet the specific needs of the partner enterprise. In addition, the provider participates in the development of new technology and products. In return, the enterprise participates in school management and provides funding, equipment, workplace practice and a number of specialized instructors. This model offered the enterprise the opportunity to take part in school administration as well as monitoring teaching quality. The students on the other hand have the opportunity to build an employee network and eventually employed by the enterprise on completion of their studies.

\section{(c) The Zero Period of Adaptation Model}

Under this model, TVET institutions prepare trainees to move directly into positions without additional specific training. Courses are customized to meet the needs of identified enterprises. The process includes identifying the knowledge and skill requirements, restructuring courses and curriculum accordingly, training teachers, and establishing field practice placements within and outside the school. One of the major features of this collaboration is its emphasis on the preparation of the trainees for employment through local labour market survey and curriculum revision and development for provision of customized programs accordingly.

\section{(d) The Combined School-Factory Model}

TVE institutions establish a combined school-factory enterprise that meets the needs of a local economy. Through participation in industrial production, teachers gain experience to further develop their teaching expertise. Also, this collaboration type improves the content of curriculum.

\subsection{Consistent Teacher Development Programme}

The capacity of TVET systems to provide high quality and relevant training depends largely on the quality of its teachers and trainers, and, by extension, on the quality of their teacher training systems (ILO, 2015). A major feature of the Chinese TVET system is the organized training system for teachers and instructors at vocational schools in tune with new technologies and needs of modern industry.

In order to achieve the goal of effective teacher training programme for TVET teachers in China, a strong teacher training system was established. Beginning from 1989, more than 160 higher education institutions have established departments for the training of Vocational education teachers. At the same time the government established teacher training bases for vocational education. Ove 50 training bases have been set up by vocational technical colleges with affiliations to higher education institutes (HEIs) and more than 200 training bases are set up by central departments and local governments. Teacher training needs for vocational education of various forms and at various levels is being met by a network of training bases (MOE, PRC October 20, 2006). Furthermore, teachers in vocational schools are required to undergo one-month training in industry each year, or two months every two years for their career progression and promotion. During this time, they are provided with financial support from the school authorities. In addition, employees from industry are also hired as part-time teachers in technical and vocational institutions.

\section{Conclusion}

Investing in knowledge and skills is seen by many governments as the cornerstone of developing an employable and globally competitive work force (AFDB \& OECD, 2008). Skills and knowledge are engines of economic growth and social development of any nation. Quality education and skills not only empower the recipients for access to economically and socially rewarding jobs, but also empower them to create jobs, provide opportunities for re-integration of displaced workers and migrants and provide platform for school drop-outs and graduates to transit from school to work. (AFDB \& OECD, 2008). Investment in education for skills as well as basic health and social protection will empower people to move out of poverty, equip people to be socially mobile and to avoid exclusion, as well as improve resilience for both individuals and society as a whole (AFDB, OECD, \& UNDP, 2017).

Inclusive growth and sustainable development are dependent on a blend between investment in skills and knowledge and provision of enabling environment for skills utilization like infrastructures, efficient markets and investment in innovation which are key components for driving sustained growth and prosperity (World Economic Forum, 2017). Skilled and knowledgeable workforce not only improve a country's investment climate, it is also a 
major determinant of productivity and growth as well as international competitiveness (AFDB \& OECD, 2008). The transformation of African economies into globally competitive economies with abundant opportunities for decent work for the young population which constitute a large portion of the continent's population has been hinged on investment in human capital development through acquisition of relevant skills and knowledge (World Economic Forum, 2015). The general consensus among countries globally is that TVET plays significant role in economic development, but the increased awareness notwithstanding, provision of TVET in African countries is hampered by lack of funds as many countries on the continent have not been able to finance TVET at a level that can support quality training. The region faces the enormous challenge of providing stable and sustained socioeconomic development that will provide room to lift the region's young population out of poverty induced by unemployment and protect the region from poverty-triggered insecurity.

The Chinese successful TVET model provides new perspectives for research on TVET from the perspective of the Chinese model of TVE and the theory behind it. The unique provision of TVET in China as vigorously promoted by the government in line with the national development agenda makes TVET exert strong impact on the society at the period when theories postulated by western researchers claimed investment in TVE was not profitable especially for developing countries. The Chinese experience provides a platform for African countries to adopt successful experience from the Chinese TVET model for the promotion of sustainable development on the country.

\section{References}

Adams, A. V. (2008). Skills Development in the Informal Sector of Sub-Saharan Africa. Washington D.C.

Adams, A. V., Johansson de Silva, S., \& Razmara, S. (2013). Improving Skills Development in the Informal Sector Strategies for Sub-Saharan Africa. https://doi.org/10.1596/978-0-8213-9968-2

AFDB, \& OECD. (2008). African Economic Outlook 2008.

African Union. (2007). Strategy to Revitalize Technical and Vocational Education and Training (TVET) in Africa. Meeting of the Bureau of the Conference of Ministers of Education of the African Union (COMEDAF II+). Retrieved from www. africa-union.org

Archer, M. S. (2013). Social origins of educational systems. Routledge.

Asian Development Bank. (2009). Financing Technical and Vocational Education and Training in the People's Republic of China.

Bennell, P., \& Segerstrom, J. (1998). Vocational education and training in developing countries: has the World Bank got it right? International Journal of Educational Development, 18(4), 271-287. https://doi.org/10.1016/S0738-0593(98)00021-2

Chen, M. (2016a). 中国职业教育改革与发展实践. (（中国改革开放与发展实践丛书/刘洪武), Ed.) (第1 版). 沈阳: 辽宁教育出版社.

Chen, M. (2016b). 中国职业教育改革与发展实践 Practice of Reform and Development of Vocational Education in China. (L. Hongwu, Ed.) (1st ed.). Shenyang: Liaoning Education Publishers.

Dike, V. E. (2009). Addressing Youth Unemployment and Poverty in Nigeria: A Call for Action, not Rhetoric. Journal of Sustainable Development in Africa (Volume 11, No.3, 2009), 11(3), 129-151.

Federal Minstry of Education Nigeria. (2005). Nigeria Education Sector Diagnosis: A Framework for Reengineering the Education Sector.

Guo, Z., \& Lamb, S. (2010). International Comparisons of China's Technical and Vocational Education and Training System (Vol. 12). Dordrecht: Springer Netherlands. https://doi.org/10.1007/978-90-481-8743-0

IAMR. (2013). Understanding Skill Development and Training in China: Lessons for India.

ILO. (2015). Vocational Teachers and Trainers in a Changing World: the Imperative of High-Quality Teacher Training Systems. Employment Policy Department EMPLOYMENT Working Paper. Geneva, Switzerland. Retrieved from http://www.ilo.org/wcmsp5/groups/public/--ed_emp/documents/publication/wcms_383787.pdf

ILO. (2019). World Employment Social Outlook: Trends 2019. Geneva: International Labour Organization. Retrieved from http://www.ilo.org/wcmsp5/groups/public/---dgreports/---dcomm/--publ/documents/publication/wcms_615594.pdf 
Joo, L. (2013). Study of Industry Linkage in China's TVET System. In Human Development: Education and Health Policy (p. 8).

K.R.E. Okoye, Okwelle, P. C. (2014). Technical Vocational Education and Training ( TVET ) as Intervention Mechanism for Global Competitiveness : Perspectives from Nigeria. Developing Country Studies, 4(4), 85-91. Retrieved from www.iiste.org

Keating, J., Medrich, E., Volkoff, V., \& Perry, J. (2002). Comparative Study of Vocational Education and Training Systems: national Vocational and Training Systems Across Three Regions Under Pressure of Chnage. NCVER Ltd. Retrieved from https://www.ncver.edu.au/_data/assets/file/0025/9754/comparative-study-of-vet-systems-863.pdf

Kurlantzick, J. (2005). How China is Changing Global Diplomacy. Retrieved from http://www.cerium.ca/article1267.html

Lewis, T. (2009). International Journal of Educational Development Towards reclaiming the high ground in the discourse on vocationalism in developing countries, 29, 558-564. https://doi.org/10.1016/j.ijedudev.2009.01.002

Maclean, R., \& Wilson, D. (2009). International Handbook of Education for the Changing World of Work. (R. Maclean \& D. Wilson, Eds.). Dordrecht: Springer Netherlands. https://doi.org/10.1007/978-1-4020-5281-1

Ministry of Education PRC. (2015). 中国教育年鉴China Education Yearbook 2015. (宋德民 \& 李曜升, Eds.) (1st ed.). Beijing: 人民教育出版社. Retrieved from http://www.pep.com.cn

Moja, T. (2000). Nigeria education sector analysis: An analytical synthesis of performance and main issues. World Bank Report. WORLD BANK Report, (January), 26-28. Retrieved from http://siteresources.worldbank.org/NIGERIAEXTN/Resources/ed_sec_analysis.pdf

National Bureau of Statistics China. (2016a). China's Urbanization Process 中国城镇化进程. Retrieved October 8, 2017, from http://data.stats.gov.cn/swf.htm?m=turnto\&id=432

National Bureau of Statistics China. (2016b). China Statistical Yearbook 2016. Retrieved September 18, 2018, from http://www.stats.gov.cn/tjsj/ndsj/2016/indexeh.htm

Okoye, R., \& Arimonu, M. O. (2016). Technical and Vocational Education in Nigeria : Issues, Challenges and a Way Forward, 7(3), 113-118.

Oni, C. S. (2006). Vocationalism in Nigerian Education. Journal of Social Science, 12(2), 147-150.

Osidipe, A. (2017). TVET and Nurturing Skills for Sustainable Regional Development : Perspectives from West Africa. Journal of Education and Practice, 8(30), 172-180. Retrieved from www.iiste.org

Oviawe, J. I. (2015). Sustaining Students 'Interest in Prevocational Education : A Strategy for Fostering Enrolment into Technical Colleges in Nigeria. International Journal of Academic Research in Progressive Education and Development, 4(3), 1-11. https://doi.org/10.6007/IJARPED/v4-i3/1765

Psacharopoulos, G. (1990). Why educational policies can fail: an overview of selected African experiences. World Bank Discussion Papers (Vol. 82).

The News. (2018, October 11). World Bank Takes Responsibilty for Advising Nigeria, Others on Biased Investment. The News Newspaper. Retrieved from https:/www.thenewsnigeria.com.ng/2018/10/worldbank-takes-responsibility-for-advising-nigeria-others-on-biased-investment/

Tikly, L. (2013). Reconceptualizing TVET and Development: a Human Capability and Social Justice Approach. Revisiting Global Trends in TVET: Reflections on Theory and Practice, 3-39. Retrieved from http://www.unevoc.unesco.org/go.php?q=Revisiting global trends in TVET Reflections on theory and practice

UN, DESA, \& Pupulation Division. (2017). World Population Prospects 2017 Revision: Demographic Profiles (Vol. II). Retrieved from https://population.un.org/wpp/Publications/Files/WPP2017_Volume-IIDemographic-Profiles.pdf

UNESCO. (2019). Technical and Vocational Education and Training at UNESCO's Office in Dakar | United Nations Educational, Scientific and Cultural Organization. Retrieved July 8, 2019, from http://www.unesco.org/new/en/dakar/education/technical-and-vocational-education-and-training/

UNESCO, \& ILO. (2002). Technical and Vocational Education and Training for the Twenty-first Century. United Nations Educational. Scientific and Cultural Organization (UNESCO) and International Labour 
Organization (ILO). Retrieved from http://unesdoc.unesco.org/images/0012/001260/126050e.pdf

Watson, K. (1994). Technical and Vocational Education in Developing Countries: Western paradigms and comparative methodology. Comparative Education, 30(2), 85-97. https://doi.org/10.1080/0305006940300202

Wilson, D. (2001). Reform of TVET for the changing world of work. Prospects, 31(1), 21-37. https://doi.org/10.1007/BF03220047

World Economic Forum. (2016). The Future of Jobs Employment, Skills and Workforce Strategy for the Fourth Industrial Revolution. Global Challenge Insight Report.

Wu, X., \& Ye, Y. (2009). Technical and Vocational Education in China. (C. Socol, Ed.) (1st ed.). Hangzhou: Zhejiang University Press.

Xiulan, Z. (Ed.). (2011). China's Education Development and Policy 1978-2008. Social Scientific Studies in Reform Era China (Vol. 9). Netherlands: Brill.

Zhaoli, C. (2013). 职业教育集团化办学试点项目实施方案. (蔡钊利, Ed.) (1st ed.). 西安: 西安电子科技大学 出版社. 